\title{
Induction and characterization of monoclonal anti-idiotypic antibodies reactive with idiotopes of canine parvovirus neutralizing monoclonal antibodies*
}

\author{
G.F. Rimmelzwaan, J.H. van Es, G. Drost, F.G.C.M. UytdeHaag and \\ A.D.M.E. Osterhaus \\ Department of Immunobiology, National Institute of Public Health and Environmental Protection, \\ P.O. Box 1, 3720 BA Bilthoven, Netherlands
}

(Accepted 26 September 1990)

\begin{abstract}
Rimmelzwaan, G.F., van Es, J.H., Drost, G., UytdeHaag, F.G.C.M. and Osterhaus, A.D.M.E., 1991 . Induction and characterization of monoclonal anti-idiotypic antibodies reactive with idiotopes of canine parvovirus neutralizing monoclonal antibodies. Vet. Immunol. Immunopathol., 29: 139150.

Monoclonal anti-idiotypic (anti-Id) antibodies (Ab2) were generated against idiotypes (Id) of canine parvovirus (CPV) specific monoclonal antibodies (MoAbs). The binding of most of these anti-Id antibodies to their corresponding Id could be inhibited by antigen, thus classifying these anti-

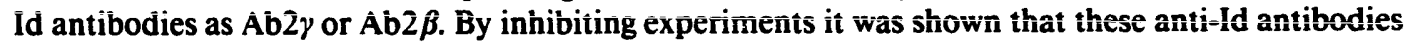
did not recognize interspecies cross-reactive idiotopes, but recognized private idiotopes, uniquely associated with the Id of the anti-CPV MoAb used for immunization. This classifies these anti-Id antibodies as non-internal image $A b 2 \gamma$. The potential use of these non-internal image anti-Id antibodies for the induction of antiviral antibodies in the CPV system is discussed.
\end{abstract}

\section{ABBREVIATIONS}

BSA, bovine serum albumin; CPV, canine parvovirus; ELISA, enzyme-linked immunosorbent assay; FPV, feline parvovirus; HRP, horseradish peroxidase; IAC, immunoaffinity chromatography; Id, idiotypes; KLH, keyhole limpet haemocyanin; MoAb, monoclonal antibodies; PBS, phosphate-buffered saline; SPF, specific pathogen free; TMB, tetramethylbenzidine.

\section{INTRODUCTION}

Canine parvovirus (CPV) is a member of the autonomous parvoviruses and is associated with enteritis and myocarditis in dogs. Since the virus was

"This work was supported by "De bond tot bescherming van Honden", The Hague, Netherlands. 
discovered in 1978 (Appel et al., 1979; Burtonboy et al., 1979; Osterhaus et al., 1980; Gagnon and Povey, 1979), inactivated or live attenuated vaccines have been used to prevent the disease. Owing to the presence of maternally derived antibodies. conventional vaccines may fail to induce protection in pups up to 16 weeks of age (Pollock and Carmichael, 1982).

Recent developments in molecular biology and immunology may provide alternative vaccine strategies, based on the use of recombinant organisms, their products or synthetic peptides. A completely different approach, which might perhaps aiso overcome the interference by maternal antibodies, is the use of idiotypic structures for manipulation of the immune response towards immunity against CPV.

Since Jerne proposed his idiotypic network theory (Jerne, 1974), much attention has been given to anti-idiotypic (anti-Id) antibodies as vaccin : candidates against numerous infectious pathogens (Nisonoff and Lamoyi, i.981). The successful induction of a specific immune response to several viral antigens with anti-Id antibodies has been described (for review see Rimmelzwaan et al., 1989).

Idiotypes (Id) are associated with the variable region of antibody molecules and are formed by the total set of determinants of the variable region, which are called idiotopes (Kunkel et al., 1963; Oudin and Michel, 1963). Idiotypes have been defined by serological means, using anti-Id antibody preparations (Ab2) generated against the Id of the antibody reactive with the antigen (Ab1). Different types of anti-Id antibodies can be distinguished (Jerne et al., 1982). Ab2 $\alpha$ recognize idiotopes associated with the framework or the paratope of $\mathrm{Abl}$. The binding of $\mathrm{Ab} 2 \alpha$ to $\mathrm{Ab1}$ may or may not be inhibited by antigen. If the binding of $A b 2 \alpha$ to $A b 1$ is inhibitable by antigen, $\mathrm{Ab} 2 \alpha$ are said to recognize paratope-related idiotopes. These kinds of $\mathrm{Ab} 2 \alpha$ are sometimes referred to as $\mathrm{Ab} 2 \gamma$. Ab2 $\beta$ are anti-Id antibodies which mimic an antigenic determinant and bind like the epitope of an antigen to $A b 1$. The binding of $A b 2 \beta$ to $A b 1$ should be inhibitable by antigen and $A 2 \beta$ should recognize Id from several species induced by immunization with the same antigen (interspecies cross-reactive Id). Furthermore, $A b 2 \beta$ must be able to induce an antibody response of the same specificity as the epitope that it mimics in different animal species or strains. Although Ab2 not displaying Ab2 $\beta$ properties should not fully be excluded as candidates for immunization purposes (Francotte and Urbain, 1984; Schick et al., 1987; Zhou et al., 1987; Anders et al., 1989), true Ab2 $\beta$ should preferentially be considered for this purpose.

In this report we describe the generation and characterization of mouse monoclonal antibodies (MoAbs) recognizing Id CPV neutralizing MoAbs. These anti-id antibodies did not fulfil all the criteria for $A b 2 \beta$ and were classified as $A b 2 \gamma$, reactive with private idiotopes (idiotopes uniquely associated with a given antibody molecule) of their respective $\mathrm{Abl}$. The potential use of 
these non-internal image anti-Id antibodies in immunization against CPV is discussed.

\section{MATERIALS AND METHODS}

\section{Animals}

BALB/c mice were raised in the animal facility of the National Institute of Public Health and Environmental Protection and were kept under specificpathogen-free (SPF) conditions.

Three 2-year-old SPF cats, free from all the known feline viruses, were kept under barrier-contained conditions. Two 3-year-old SPF dogs, free from all the known canine viruses, were kept under barrier-contained conditions.

\section{CPV antigen}

CPV antigen was purified by immunoaffinity chromatography (IAC) from culture supernatant as described previously (Rimmelzwaan et al., 1987).

\section{Monoclonal antibodies}

The production, selection and characterization of MoAbs to CPV have been described previously (Rimmelzwaan et al., 1987). Two of these virus neutralizing MoAbs, H-1 (IgG2a $\kappa$ ) and H-2 (IgG2b $\kappa$ ), each recognizing a different epitope of the haemagglutinating protein of CPV were used to induce monoclonal Ab2. MoAbs $\mathrm{H}-1$ and $\mathrm{H}-2$ were purified from ascitic fluid by affinity chromatography with protein-A sepharose essentially as indicated by the manuiacturer (Pharmacia Fine Chemicals, Uppsala) and conjugated to keyhole limpet hemocyanin (KLH) (Calbiochem, La Jolla, CA) with glutaraldehyde as previously described (Legrain et al., 1985).

BALB/c mice were immunized subcutaneously by multipoint dose injections on Day 0 with $150 \mu \mathrm{g}$ MoAb H-1 or H-2 conjugated to KLH in complete Freund's adjuvant (Difco Laboratories, Detroit) followed by subcutaneous multipoint dose booster injections of $150 \mu \mathrm{g}$ in incomplete Freund's adjuvant at Day 14. After three intraperitoneal or intravenous injections with $100 \mu \mathrm{g}$ purified MoAb H-1 or MoAb H-2 on Days 28, 29 and 30, spleen cells were fused on Day 34 with mouse myeloma cells as described previously (Osterhaus et al., 1981 ). Hybridomas were single cell cloned twice before their antiId MoAbs were used. Isotypes of MoAbs were determined in an ELISA system according to the prescriptions of the manufacturer (Zymed Laboratories Inc., San Francisco, CA).

\section{F $\left(a b^{\prime}\right)_{2}$ or Fab fragments of MoAbs $\mathrm{H}-1$ and $\mathrm{H}-2$}

$\mathbf{F}\left(\mathrm{ab}^{\prime}\right)_{2}$ fragments were prepared from protein-A sepharose purified MoAb H-1 or control MoAb (IgG2a) by pepsin digestion. Purified IgG was dialyzed against saline for $16 \mathrm{~h}$ at $4^{\circ} \mathrm{C}$. The solution was adjusted to pH 3.8 with 0.1 
$\mathrm{N} \mathrm{HCl}$. One hundred units of pepsin (Cappel, Cooper Biomedical, Malvern) were added per milligram of IgG. After incubation at $37^{\circ} \mathrm{C}$ for $24 \mathrm{~h}$ the solution was adjusted to $\mathrm{pH} 8.0$ with $0.1 \mathrm{~N} \mathrm{NaOH}$ and was dialyzed against phosphate buffer $\mathrm{pH} 8.1$ for $16 \mathrm{~h}$ at $4^{\circ} \mathrm{C}$. $\mathrm{F}\left(\mathrm{ab}^{\prime}\right)_{2}$ fragments were isolated by chromatography on protein-A sepharose. The purity of the $F\left(a b^{\prime}\right)_{2}$ fragments thus obtained was monitored by ELISA. Fifty microliter volumes of serial dilutions in carbonate buffer pH 9.6 of $\mathrm{F}(\mathrm{ab})_{2}$ fragments and starting material were coated for $2 \mathrm{~h}$ at $37^{\circ} \mathrm{C}$ onto microtiter plates (Titertek, Flow Laboratories). The plates were washed with demineralized water containing $0.05 \%$ Tween 80 and blocked with PBS containing $1 \%$ bovine serum albumin (BSA) (Organon Teknika, Oss, Netherlands). The extent of degradation was determined using horseradish peroxidase (HRP)-conjugated sheep anti-mouse IgG and goat anti-mouse IgG (gamma chain-specific) (Cappel, Cooper Biomedical, Malvern, U.S.A.). After incubation for $1 \mathrm{~h}$ at $37^{\circ} \mathrm{C}$, the plates were washed and $0.1 \mathrm{ml}$ volumes of substrate solution $(0.1 \mathrm{mg} / \mathrm{ml}$ tetramethylbenzidine (TMB) (Sigma, St. Louis)) and $0.003 \% \mathrm{H}_{2} \mathrm{O}_{2}$ in $0.1 \mathrm{M} \mathrm{NaAc}$ buffer pH 5.5 were added to each well. The reaction was stopped after $10 \mathrm{~min}$ by adding $0.1 \mathrm{ml} 2 \mathrm{M} \mathrm{H}_{2} \mathrm{SO}_{4}$. The absorbence was read in a Titertek Multiscan (Flow Laboratories).

Fab fragments were prepared from purified MoAb H-2 (IgG2b) by papain digestion. Ten to twenty micrograms of papain (Worthington, Flow Laboratories) were activated during $30 \mathrm{~min}$ at $37^{\circ} \mathrm{C}$ in $0.1 \mathrm{M}$ phosphate buffer $\mathrm{pH}$ 7.8 containing $2 \mathrm{mM}$ EDTA and $10 \mathrm{mM}$ cysteine and were added to the IgG solution $(1 \mathrm{mg} / \mathrm{ml})$. After $4 \mathrm{~h}$, the digestion was stopped by adding sodium acetamid at a final concentration of $10 \mathrm{mM}\left(20 \mathrm{~min}\right.$ at $\left.37^{\circ} \mathrm{C}\right)$. The solutic $\mathrm{n}$ was dialyzed and monovalent Fab were separated from Fc fragments and undegraded IgG by chromatography on protein-A sepharose. The extent of papain digestion was monitored by ELISA as described above.

\section{Indirect ELISA for the detection of anti-Id (Ab2) antibodies}

Microtiter plates were coated with $\mathrm{F}\left(\mathbf{a b}^{\prime}\right)_{2}$ or $\mathbf{F a b}$ fragment preparations of protein-A-purified MoAbs $\mathrm{H}-1$ and $\mathrm{H}-2$ and of control MoAbs by incubating $50 \mu \mathrm{l}$ volumes for $16 \mathrm{~h}$ at $4^{\circ} \mathrm{C}$ at a concentration of $4-6 \mu \mathrm{g} / \mathrm{ml}$ in carbonate buffer $\mathrm{pH}$ 9.6. After blocking with PBS containing $0.05 \%$ Tween 80 and $1 \% \mathrm{BSA}, 50 \mu \mathrm{l}$ volumes of hybridoma culture supernatants containing anti-Id antibodies were added to each well. Binding of $\mathrm{Ab} 2$ to $\mathrm{Ab1}$ was detected by adding $50 \mu \mathrm{l}$ of HRP-conjugated goat anti-mouse IgG Fc (Cappel, Cooper Biomedical, Malvern, U.S.A.) to each well. After each incubation, the plates were washed with demineralized water containing $0.05 \%$ Tween 80 . The plates were developed with TMB substrate as described above. 
Idiotope cross-linking ELISA for the detection of anti-Id antibodies (Ab2) or anti-anti-Id antibodies (Ab3)

Protein-A-purified H-1 (IgG2a), H-2 (IgG2b) and control mouse MoAbs of the same isotype were bound onto micro ELISA plates (Titertek type III, Flow Laboratories) by incubating $50 \mu$ l volumes per well at a concentration of $4-6 \mu \mathrm{g} / \mathrm{ml}$ in $0.1 \mathrm{M}$ carbonate buffer $\mathrm{pH} 9.6$ at $20^{\circ} \mathrm{C}$. After blocking the plates with PBS containing $0.06 \%$ Tween 80 and $1 \%$ BSA $50 \mu \mathrm{l}$ of hybridoma culture supernatant fluids containing anti-Abl antibody were transferred to $\mathrm{Abl}$-coated plates. After $1 \mathrm{~h}$ at $37^{\circ} \mathrm{C}$, binding of $\mathrm{Ab} 2$ to $\mathrm{Abl}$ was detected by the detection of $50 \mu \mathrm{l}$ of HRP-conjugated protein-A-purified Ab1. Plates were developed as described above using TMB as a substrate. After $10 \mathrm{~min}$ the reaction was stopped with $2 \mathrm{M} \mathrm{H}_{2} \mathrm{SO}_{4}$. The absorbence was read at $450 \mathrm{~nm}$ (A450) by using a Titertek Multiscan automatic plate reader (Flow Laboratories). Essentially the same technique was used for the demonstration of Ab3, using plate bound and HRP-conjugated purified monoclonal Ab2.

\section{Inhibition ELISA for the detection of paratope-related idiotopes}

Inhibition of the binding of anti-Id antibodies to $F\left(\mathbf{a b}^{\prime}\right)_{2}$ and Fab fragments of their homologous plate-bound $\mathrm{Abl}$ by $\mathrm{CPV}$ was considered to be indicative for specificity for antigen binding site-related idiotopes of Ab1. Twofold serial dilutions of IAC-CPV were transferred to plates coated with $\mathrm{F}(\mathrm{ab})_{2}$ fragments of MoAb $\mathrm{H}-1$ or $\mathrm{H}-2$, respectively. Controls were performed by incubation with diluent (PBS, containing $0.05 \%$ and $1 \% \mathrm{BSA}$ ), without viral antigen. After incubation for $1 \mathrm{~h}$ at $37^{\circ} \mathrm{C}, 50 \mu \mathrm{l}$ volumes of hybridoma culture supernatant containing anti-Id antibodies were added at a concentration of $75 \%$ of maximal level of binding when tested without inhibition. The remaining binding of $A b 2$ was detected by the addition of HRPconjugated goat IgG anti-mouse IgG gamma chain-specific (Cappel, Cooper Biomedical, Malvern, U.S.A.). The plates were washed after each incubation with demineralized water containing $0.05 \%$ Tween 80 . The plates were further developed as described above. The percentage of inhibition was calculated according to the formula:

Inhibition $=\frac{\text { A450 uninhibited }- \text { A450 inhibited }}{\text { A450 uninhibited }} \times 100$

\section{Inhibition ELISA for Id specificity}

To determine the Id specificity of the anti-Id antibodies, inhibition studies were performed with HRP-conjugated protein-A sepharose-purified Ab2. Plates were coated with $50 \mu \mathrm{l}$ volumes of MoAb $\bar{H}-1$ or H-2 (200-300 ng per well in $0.1 \mathrm{M}$ carbonate buffer $\mathrm{pH} \mathrm{9.6).} \mathrm{Tenfold} \mathrm{serial} \mathrm{dilutions} \mathrm{of} \mathrm{Ab2}$ were allowed to bind to their plate-bound homologous $\mathrm{Abl}$ for $1 \mathrm{~h}$ at $37^{\circ} \mathrm{C}$. Plates were then incubated with $50 \mu \mathrm{l}$ volumes of HRP-conjugated $\mathrm{Ab} 2$ at a dilution 
giving $75 \%$ of maximum binding of $\mathrm{Ab2}$. The plates were washed after each incubation and developed as described above. Inhibition percentages were also calculated as described above.

\section{Inhibition ELISA for the detection of cross-reactive idiotopes}

The ability of immunoglobulins from pre-immune and immune sera of outbred SPF cats $(n=3)$, dogs $(n=2)$ and BALB/c mice (pool of 10 mice) immunized with FPV or CPV and of MoAbs to CPV, to react with Ab2 was tested. The anti-CPV titers of the immune sera ranged from 300 to 2000 in haemagglutination inhibition tests. The titer of ascitic fluids of the anti-CPV MoAbs ranged from $10^{4}$ to $5 \times 10^{4}$. Inhibition of the binding of $\mathrm{Ab} 2$ to $\mathrm{Ab} 1$ by hyperimmune sera was supposed to be indicative for the recognition of interspecies cross-reactive idiotopes. Thirty microliters of Ab2 culture supernatants giving $75 \%$ of maximum binding in the indirect ELISA on $F\left(a b^{\prime}\right)_{2}$ or Fab fragments were incubated with equal volumes of dilutions of the respective inhibitors for $16 \mathrm{~h}$ at $4^{\circ} \mathrm{C}$. The remaining anti-Abl reactivity was assayed in the indirect ELISA on $F\left(a b^{\prime}\right)_{2}$ or Fab fragments as described above. Inhibition percentages were also calculated as described above.

\section{RESULTS}

Generation and selection of Id-specific MoAbs

The Id specificity of anti-Id MoAbs generated was assayed in the indirect ELISA or the Ids cross-linking ELISA using plate-bound Abl or isotype matched MoAbs as controls. From seven fusion events, a total of 33 hybridomas could be isolated, that produced antibodies reactive with the Id of CPV neutralizing MoAb H-1 (31 of 33) or the Id of CPV neutralizing MoAb H-2 ( 2 of 33 ), but not with control Id, in the indirect ELISA and in most cases also in the cross-linking ELISA. The two anti-Id MoAbs directed to anti-CPV MoAb H-2 and five of the anti-Id MoAbs directed to anti-CPV MoAb H-1, which were arbitrarily chosen from a panel of 11 anti-Id MoAbs that showed positive reactivity in both ELISAs and of which the binding to Id-coated plates could be inhibited by IAC-CPV, were selected for further study. This is because inhibition by antigen is considered to be one of the criteria for defining an anti-Id antibody as an internal image of an antigenic determinant. The Id specificities of these MoAbs are shown in Table 1. Culture supernatants of $\mathrm{Ab} 2$ secreting hybridomas showed binding to the respective Ab1 used for immunization but not to isotype matched mouse MoAb. The specificities of these anti-Id MoAbs for the respective Abl were further confirmed in the inhibition ELISA. All MoAbs directed to anti-CPV MoAb H-1 failed to inhibit the binding of anti-Id MoAb 2-2-9 to anti-CPV MoAb H-2 and MoAbs to antiCPV MoAb H-2 also failed to inhibit the binding of anti-Id MoAb 6-14-18 directed to MoAb H-1 (Table 2). 


\section{TABLE 1}

Id-specificity of selected MoAbs (culture supernatants) directed to anti-CPV MoAbs (Ab1) as determined in indirect and cross-linking ELISA

\begin{tabular}{|c|c|c|c|c|c|c|}
\hline \multirow[t]{2}{*}{$\begin{array}{l}\text { Anti-Id } \\
\text { MoAb } \\
\text { (Ab2) }\end{array}$} & \multirow[t]{2}{*}{ Isotype } & \multirow{2}{*}{$\begin{array}{l}\text { Directed to } \\
\text { anti-CPV } \\
\text { MoALbl } \\
\text { (Ab1) } \\
\text { Indirect } \\
\text { ELISA }\end{array}$} & Binding & Control $\mathrm{N}$ & ith Id ( $A$ & 50) \\
\hline & & & $\begin{array}{l}\text { Cross- } \\
\text { linking } \\
\text { ELISA }\end{array}$ & $\begin{array}{l}\text { Indirect } \\
\text { ELISA }\end{array}$ & $\begin{array}{l}\text { Cross- } \\
\text { linking } \\
\text { ELISA }\end{array}$ & \\
\hline $1-7-4$ & IgG1 & ) & 1669 & 1607 & $<65$ & 74 \\
\hline $2-23-9$ & IgG1 & & 1906 & 1463 & $<65$ & 92 \\
\hline $5-3-1$ & IgG3 & H-1 (IgG2a) & 718 & 1280 & $<65$ & 83 \\
\hline $6-14-18$ & IgGI & & 223 & 1429 & $<65$ & 80 \\
\hline $6-23-15$ & IgG1 & & 830 & 1455 & $<65$ & 72 \\
\hline $2-2-9$ & IgG1 & $\mathrm{H} 2(\mathrm{I \sigma C2} \mathrm{b}$ & 1772 & 576 & 168 & $\mathrm{NT}^{2}$ \\
\hline $6-16-9$ & IgG1 & $\mathrm{H}-2(\mathrm{IgG} 2 \mathrm{~b})$ & 747 & 625 & 128 & NT \\
\hline
\end{tabular}

'Isotype matched control mouse Id.

${ }^{2} \mathrm{NT}$, not tested.

TABLE 2

Inhibition ELISA for the demonstration of Id specificity of anti-Id MoAbs

\begin{tabular}{|c|c|c|c|}
\hline \multirow{2}{*}{$\begin{array}{l}\text { Inhibitor: anti-Id MoAb } \\
\text { (Ab2) }\end{array}$} & \multirow{2}{*}{$\begin{array}{l}\text { Anti-CPV MoAb } \\
\text { (Abl) }\end{array}$} & \multicolumn{2}{|c|}{ HRP-conjugated anti-Id MoAb (Ab2) } \\
\hline & & $2-2-9$ & $6-14-18$ \\
\hline $\begin{array}{l}2-2-9 \\
6-16-9 \\
1-7-4 \\
2-23-9 \\
5-3-1 \\
6-14-18 \\
6-23-15\end{array}$ & $\mathbf{H}-\mathbf{1}$ & $\begin{array}{l}\quad++i \\
++++ \\
- \\
- \\
- \\
- \\
-\end{array}$ & $\begin{array}{r}- \\
- \\
++++ \\
++++ \\
++ \\
+++ \\
++\end{array}$ \\
\hline
\end{tabular}

'Units indicating the percentage of inhibition of binding of HRP-conjugated anti-Id MoAb (Ab2) to plate-bound anti-CPV MoAb (Abl).

-, <10\%; +, 10-25\%; + +, 25-50\%; + + +, 50-75\%; + + + +, 75-100\%.

In order to classify the anti-Id MoAbs as either $\mathrm{Ab} 2 \alpha, \mathrm{Ab} 2 \beta$ or $\mathrm{Ab} 2 \gamma$ inhibition experiments with IAC-CPV antigen were performed. Therefore we examined whether the binding of $\mathrm{Ab} 2$ to $\mathrm{Ab} 1$ could be inhibited by different amounts of CPV. As shown in Table 3, IAC-CPV could significantitly (2095\%) inhibit the binding of these seven selected anti-Id MoAbs to their respective $\mathrm{Ab1}$, thus classifying these anti-Id MoAbs as either Ab2 $\gamma$ or Ab2 $\beta$. Among the anti-Id MoAbs, that were not selected for further evaluation, 12 could not be inhibited to bind to their corresponding Ab1 with IAC-CPV an- 
TABLE 3

Detection of combining site related idiotopes on $A b l$ by inhibition of their reactivities $F\left(a b^{\prime}\right)_{2}$ or Fab fragments of anti-Id MoAbs with IAC-CPV

\begin{tabular}{llcll}
\hline Clone & \multicolumn{4}{l}{ IAC-CPV $(\mu \mathrm{g})$} \\
\cline { 2 - 5 } & 1.25 & 0.6 & 0.3 & 0.15 \\
\hline $1-7-4$ & $42^{1}$ & 26 & 7 & 3 \\
$2-23-9$ & 44 & 39 & $\mathrm{NT}^{2}$ & $\mathrm{NT}$ \\
$5-3-1$ & 42 & 20 & 6 & 5 \\
$6-14-18$ & 64 & 21 & 9 & 6 \\
$6-23-15$ & 95 & 53 & 26 & 7 \\
$2-2-9$ & 34 & 40 & 0 & 0 \\
$6-16-9$ & 42 & 22 & 5 & 0 \\
$1-2^{3}$ & 9 & 0 & 0 & 0 \\
\hline
\end{tabular}

'Percent inhibition.

'NT, not tested.

${ }^{3}$ Non-selected anti-Id MoAb (Ab2).

tigen ( $<10 \%$ inhibition; not shown) and should therefore be considered to be non-internal image $\mathrm{Ab} 2 \alpha$, the other 14 could be inhibited in this assay ( $>20 \%$ inhibition). This confirmed the specificity of the observed inhibition by IAC-CPV in the seven selected anti-Id MoAbs.

Determination of interspecies cross reactivities of selected anti-Id MoAbs

In order to determine whether the seven selected anti-Id MoAbs displayed true internal image $\mathrm{A} \overline{\mathrm{b}} \mathbf{2} \hat{\beta}$ activity, we examined the ability of $\operatorname{dog}(n=2)$, cat $(n=3)$ and mouse anti-CPV serum antibodies to inhibit the Id-anti-Id reaction between the anti-CPV MoAb (Ab1) and the respective anti-Id MoAbs (Ab2). As shown in Table 4, the homologous Ab1, used in the process of generating the respective anti-Id MoAbs, inhibited these reactivities almost completely $(63-100 \%)$. None of the polyclonal antibody preparations, including the BALB/c mouse anti-CPV pooled serum, resulted in an inhibition in this assay. Thus the anti-Id MoAbs recognized idiotopes, which were not expressed in the normal response of the respective species to CPV, including $\mathrm{BALB} / \mathrm{c}$ mice. Therefore it was concluded that they all define private, combining site related idiotopes on the respective $\mathrm{Ab} 1(\mathrm{Ab} 2 \gamma)$ and are non internal image $A b 2 \beta$.

Immunization of $B A L B / c$ mice with $A b 2$

To investigate whether antiviral antibodies could be induced with Ab2 $\gamma$ in this system, three BALB/c mice were immunized with one of the following arbitrarily chosen Ab2: 2-23-9, 6-23-15 or 6-16-9. The immunization proto- 
TABLE 4

Determination of interspecies cross-reactivities of selected anti-Id MoAbs by inhibition of ELISA

\begin{tabular}{|c|c|c|c|c|c|c|c|}
\hline & \multicolumn{7}{|c|}{ HRP-conjugated ariti-Id MoAbs } \\
\hline & $1-7-4$ & $2-23-9$ & $5-3-1$ & $6=14-18$ & $6-23-15$ & $2-2-9$ & $6-16-9$ \\
\hline \multicolumn{8}{|l|}{ Inhibitor } \\
\hline Cat 1 pre-serum & $<5^{1}$ & $<5$ & $<5$ & $<5$ & $<5$ & $<5$ & $<5$ \\
\hline 2 pre-serum & $<5$ & $<5$ & $<5$ & $<5$ & $<5$ & $<5$ & $<5$ \\
\hline 3 pre-serum & $<5$ & $<5$ & $<5$ & $<5$ & $<5$ & $<5$ & $<5$ \\
\hline Cat 1 anti-FPV serum & $<5$ & $<5$ & $<5$ & $<5$ & $<5$ & $<5$ & $<5$ \\
\hline 2 anti-FPV serum & $<5$ & $<5$ & $<5$ & $<5$ & $<5$ & $<5$ & $<5$ \\
\hline 3 anti-FPV serum & $<5$ & $<5$ & $<5$ & $<5$ & $<5$ & $<5$ & $<5$ \\
\hline Dog 8 pre-serum & $<5$ & $<5$ & $<5$ & $<5$ & $<5$ & $<5$ & $<5$ \\
\hline Dog 3 anti-CPV serum & $<5$ & $<5$ & $<5$ & $<5$ & $<5$ & $<5$ & $<5$ \\
\hline 8 anti-CPV serum & $<5$ & $<5$ & $<5$ & $<5$ & $<5$ & $<5$ & $<5$ \\
\hline BALB/c mouse pre-serum & $<5$ & $<5$ & $<5$ & $<5$ & $<5$ & $<5$ & $<5$ \\
\hline BALB/c mouse anti-CPV & $<5$ & $<5$ & $<5$ & $<5$ & $<5$ & $<5$ & $<5$ \\
\hline MoAbl H-1 & 78 & 90 & 91 & 63 & 76 & $<5$ & $<5$ \\
\hline MoAb1 H-2 & $<5$ & $<5$ & $<5$ & $<5$ & $<5$ & 100 & 99 \\
\hline
\end{tabular}

'Percentage inhibition of $\mathrm{Ab2}$ of binding of anti-Id MoAb to the respective $\mathrm{Ab} 1$ by pre- and immune sera from cats, dogs and mice and by anti-CPV MoAbs H-1 and H-2.

col chosen was identical to a protocol that was successfully used in another system (Gaulton et al., 1986). Although all the mice developed high anti Ab2serum antibody titers as measured in the idiotope cross-linking ELISA (titers $10^{3}-10^{4}$ ), no CPV reactive antibodies were detected in ELISA, HI or IFA (titers less than 20).

\section{DISCUSSION}

In the strategy to generate anti-Id antibodies as vaccine candidates, one generally aims at inducing immunity with anti-Id antibodies bearing internal image $A b 2 \beta$ properties. These include the binding, to interspecies cross-reactive idiotopes, which should be inhibitable by antigen and the potential to induce an antibody response in several species of the same specificity as the epitope that is mimicked (Nisonoff and Lamoyi, 1981; Jerne et al., 1982). Such anti-Id antibodies with $\mathrm{Ab} 2 \beta$ properties have for example been utilized for the induction of virus-specific antibodies in several systems, which included poliovirus type 2 (UytdeHaag and Osterhaus, 1985), hepatitis B virus (Kennedy et al., 1986) and reovirus (Gaulton et al., 1986). However, noninternal image anti-Id antibodies have also been shown to be successful in inducing specific antibody responses to certain viruses, including human immunodeficiency virus (Zhou et al., 1987), tobacco mosaic virus (Francotte 
and Urbain, 1984), hepatitis B virus (Schick et al., 1987) and influenza virus (Anders et al., 1989).

This report describes the generation and characterization of monoclonal anti-Id antibodies directed to CPV neutralizing mouse MoAbs. However, these monoclonal anti-Id antibodies did not display all the characteristics of the true internal image $\mathrm{Ab} 2 \beta$ mentioned. Although they did not recognize combining site related idiotopes (Table 3 ), these idiotopes were not expressed in the antibody response of different animal species to CPV (Table 4) and should therefore be considered to be private idiotopes. Since also Ab2 $\alpha$ and Ab2 $\gamma$ anti-Id antibodies have been used for the induction of antiviral antibodies, we did consider the possibility of using the anti-Id MoAbs generated in the CPV system for immunization purposes. If indeed it would be feasible to induce an anti-CPV response in puppies with anti-Id antibodies defining private idiotopes, this would offer the opportunity to overcome the interference by maternally derived anti-CPV antibodies experienced in vaccination with conventional vaccines (Pollock and Carmichael, 1982). In contrast to conventional antigen or internal image $\mathrm{Ab} 2 \beta$, anti-Id antibodies recognizing private idiotopes, not normally used in the repertoire of the species in response to CPV antigen, would not be recognized by maternal antibody. In this respect it is also interesting to realize that it has been shown that administration of anti-Id antibodies in neonatal mice may lead to enhanced protection against infection with Escherichia coli (Stein and Söderström, 1984) and that idiotypic manipulation by injecting lactating mice with Id or the suckling mouse neonates with anti-Id antibodies may lead to an enhanced immune response to the F glycoprotein of respiratory syncytial virus (Okamoto et al., 1989). Our attempts to induce a specific CPV antibody response in BALB/c mice with these anti-Id monoclonal antibodies using immunization protocois which have been used in the systems described above have not been successful. Possibly other protocols, for example using sequential immunization with antiId antibodies defining private idiotopes (Legrain et al., 1985; Sanchez and Legrain, 1985) or aiming at the presentation of idiotypic structures by dendritic cells (Francotte and Urbain, 1985), which lead to the induction of antigen-specific antibodies bearing private idiotopes, may prove to be successful in the CPV system.

\section{ACKNOWLEDGEMENTS}

The authors wish to thank Ms. C. Kruyssen and Ms. M.S. Eskens for preparing the manuscript. We also thank A. Vermeulen and R. van Kinderen for biotechnical assistance. 


\section{REFERENCES}

Anders, E.M., Kapaklis-Deliyannis, G.P. and White, D.O., 1989. Induction of immune response to influenza virus with anti-Id antibodies. J. Virol., 63: 2758-2767.

Appel, M.J.G., Scott, F.W. and Carmichael, L.E., 1979. Isolation and immunisation studies of a canine parvo-like virus from dogs with haemorrhagic enteritis. Vet. Rec., 105: 156-159.

Burtonboy, G., Coignoul, F., Delferriere, N. and Pastoret, P.P., 1979. Canine hemorrhagic enteritis: detection of viral particles by electron microscopy. Arch. Virol., 61: 1-11.

Francotte, M. and Urbain, J., 1984. Induction of anti-tobacco mosaic virus antibodies in mice by rabbit antiidiotypic antibodies. J. Exp. Med., 160: 1485-1494.

Francotte, M. and Urbain, J., 1985. Enhancement of antibody response by mouse dendritic cells pulsed with tobacco mosaic virus or with rabbit antiidiotypic antibodies raised against a private rabbit idiotype. Proc. Natl. Acad. Sci. U.S.A., 82: 8149-8152.

Gagnon, A.N. and Povey, R.C., 1979. A possible parvovirus associated with an epidemic gastroenteritis of dogs in Canada. Vet. Rec., 104: 263-264.

Gaulton, G.N., Sharpe, A.H., Chang, D.W., Fields, B.N. and Greene, M.I., 1986. Syngeneic monoclonal internal image anti-idiotypes as prophylactic vaccines. J. Immunol., 137: 29302936.

Jerne, N.K., 1974. Towards a network theory of the immune system. Ann. Immunol., 125C: 373-389.

Jerne, N.K., Roland, J. and Caznave, P.A., 1982. Recurrent idiotypes and internal images. EMBO J., 1: 243-247.

Kennedy, R.C., Eichberg, J.W., Lanford, R.E. and Dreesman, G.R., 1986. Anti-idiotypic antibody vaccine for type $B$ viral hepatitis in chimparzees. Science, 232: 220-223.

Kunkel, H.G., Mannik, M. and Williams, R.C., 1963. Individual antigenic specificity of isolated antibodies. Science, 140: 1218-1219.

Legrain, P., Sanchez, P. and Buttin, G., 1985. Immune response induced by a single or several syngeneic monocional anti-ABPC48 anti-idiotypic antibodies: No predominant coexpression of ABPC48 idiotypes. Mol. Immunol., 22: 445 -453.

Nisonoff, A. and Lamoyi, E., 1981. Hypothesis. Implications of the presence of an internal image of the antigen in anti-Id antibodies: possible application to vaccine production. $J$. Immunol. Pathol., 21: 397-406.

Okamoto, Y., Tsutsumi, H., Kumar, N.S. and Ogra, P.L., 1989. Effect of breast feeding on the development of anti-idiotypic antibody response to $\mathrm{F}$ glycoprotein of respiratory syncytial virus in infant mice after post-partum maternal immunization. J. Immunol., 142: 25072512.

Osterhaus, A.D.M.E., Van Steenis, G. and De Kreek, P., 1980. Isolation of a virus closely related to feline panleukopenia virus from dogs with diarrhea. Zentralbl. Veterinaermed., Reihe B, 27: 11-21.

Osterhaus, A.D.M.E., Van Wezel, A.L., Van Steenis, B., Drost, G.A. and Hazendonk, T., 1981. Monoclonal antibodies to polioviruses. Production of specific monoclonal antibodies to the Sabin vaccine strains. Intervirology, 16: 218-224.

Oudin, J. and Michel, M., 1963. Une nouvelle forme d'allotypie des globulines du serum de Lapin apparemment liee a la fonction et a la specificite anticorps. C.R. Acad. Sci. Ser. C, 257: 805-811.

Pollock, R.V.H. and Carmichael, L.E., 1982. Maternally derived immunity to canine parvovirus infection: transfer, decline, and interference with vaccination. J. Anim. Vet. Med. Assoc., 180: $37-42$.

Rimmelzwaan, G.F., Groen, J., Juntti, N., Teppema, J.S., UytdeHaag, F.G.C.M. and Osterhaus, A.D.M.E., 1987. Purification of infectious canine parvovirus from cell culture by affinity chromatography with monoclonal antibodies. J. Virol. Methods., 15: 313-322. 
Rimmelzwaan, G.F., Bunschoten, E.J., UytdeHaag, F.G.C.M. and Osterhaus, A.D.E., 1989. Monoclonal anti-idiotypic antibody vaccines against poliovirus, canine parvovirus and rabies virus. Methods Enzymol., 178: 375-390.

Sanchez, P. and Legrain, P., 1985. The expression of a private idiotope requires pretreatment with non-complementary anti-idiotypic antibodies. Mol. Immunol., 22: 1231-1236.

Schick, M.R., Dreesman, G.R. and Kennedy, R.C., 1987. Induction of an anti-hepatitis B surface antigen response in mice by noninternal image (Ab2 $\alpha$ ) anti-Id antibodies. J. Immunol., 138: 3419-3425.

Stein, K. and Söderström, T., 1984. Neonatal administration of idiotype or antiidiotype primes for protection against Escherichia coli K13 infection in mice. J. Exp. Med., 160: 1001-1011.

UytdeHaag, F.G.C.M. and Osterhaus, A.D.M.E., 1985. Induction of neutralizing antibody in mice against poliovirus type II with monoclonal anti-Id antibody. J. Immunol., 134: 12251229.

Zhou, E.-M., Chanh, T.C., Dreesman, G.R., Kanda, P. and Kennedy, R.C., 1987. Immune response to human immtnodeficiency virus. In vivo administration of anti-idiotype induces an anti-gp 160 response specific for a synthetic peptide. J. Immunol., 139: 2950-2956. 